Um estudo de Roberto Zucco, peça teatral de Bernard-Marie Koltès. Fernanda Vieira Fernandes (Dissertação de Mestrado em Letras. Programa de Pós-Graduação em Letras, Instituto de Letras, UFRGS, 2009. Orientador: Robert Ponge).

\title{
Cabe ao palco o que É efÊMERo, À LITERATURA O QUE É ETERNO
}

A presente Dissertação é oportuna e apropriada sob muitos aspectos. Ela apresenta um mergulho profundo sobre uma obra, seu autor, contexto e possibilidades. E este é um de seus grandes trunfos. Ao quase esgotar o estudo sobre a obra, ao contrário, ela abre um profícuo caminho de possibilidades para quem quiser estudar Koltès, suas peças e o panorama do teatro contemporâneo. Ou ainda, para quem desejar encontrar neste trabalho um exercício modelar de abordagem do texto teatral seja como estudo literário, seja como estudo da cena contemporânea.

A autora faz um trabalho bastante similar ao do Dramaturg (no Brasil chamado Dramaturgista), figura criada na Alemanha e que se espalhou por inúmeras realizações teatrais, que é o elemento designado a tratar de tudo que diz respeito à obra dramatúrgica, aplainando os caminhos para a encenação. Ou provocando, questionando e inquietando.

A escrita equilibra as exigências acadêmicas de um texto correto, estruturalmente bem desenhado e repercutindo uma pesquisa feita com rigor, e a paixão vislumbrada a cada momento, da atriz encantada com o objeto de seus estudos.

A leitura do trabalho é encantadora, reveladora e inquietante. Fazemos o caminho que ela nos propõe: conhecer o fascinante Koltès, imaginar sua África, seus temores, suas doenças, seu mundo para então conhecer o irresistível Zucco, adocicado pelo autor e pela autora, para nos provocar ainda mais. Queremos subir ao telhado e nos (des)equilibrarmos ao sol, artistas que somos desejosos de voar para além de nossas raízes.

Há na leitura desta Dissertação um antigo prazer redescoberto, o do "trabalho de mesa", ${ }^{1}$ da aventura de se aproximar de um novo texto teatral, com tudo que ele nos traz de possibilidades. Estudar cena a cena, entender as intençôes de cada palavra, tecer, a partir

${ }^{1}$ Tipo de ensaio em que direção e elenco trabalham sobre o texto dramático e sua análise, antes de partir para a prática no palco. 
do texto, novas texturas de situações e emoções. E, portanto, uma ampliação da potencialidade de análise do texto dramático.

Logo de início, Fernanda aponta que seu estudo parte da opção de estudar o texto abrindo mão de verificar possibilidades de encenação e complementa: "A escolha de estudar o texto foi feita considerando que o espetáculo tem sua presença primordial, mas a riqueza da literatura dramática sem a verificação prévia dos efeitos na plateia não pode ser ignorada. Cabe ao palco o que é efêmero, à literatura o que é eterno" (p. 10).

Uma escolha acertada sem dúvida, pelos motivos apontados por ela. E também porque o texto nos oferece um prazer que ultrapassa a repercussão na cena. Ele existe por si, até porque na sua constituição está implícita a imaginação da cena. Há um prazer da palavra que se imagina falada, um prazer da rubrica vislumbrada, dos espaços, dos tempos. Durante algum tempo, o teatro contemporâneo abriu mão da palavra e do texto teatral. Era uma resposta a anos de submissão do espetáculo ao autor. Passada esta necessidade de se contrapor, o teatro redescobre a palavra concebida de todas as formas. E o texto escrito para a cena é novamente acreditado e valorizado como propulsor do acontecimento, um reconhecimento de que no seu interior pulsa a vida da encenação.

E aqui, em Roberto Zucco, como em toda obra de BernardMarie Koltès, temos o novo texto teatral. Que se liberta da ação linear, que se apropria da fragmentação da contemporaneidade.

Fernanda constrói o percurso da biografia do autor, trazendo aspectos fascinantes que mais adiante reencontraremos em sua dramaturgia. Como é o caso do profundo desejo de viajar que vários autores reconhecem em Koltès e que ele levará também a seus personagens. Não qualquer viajante, mas aquele para quem, como lembra Tomáz Tadeu da Silva,

a viagem proporciona a experiência do 'não sentir-se em casa' que, na perspectiva da teoria cultural contemporânea, caracteriza, na verdade, toda identidade cultural. $\mathrm{Na}$ viagem, podemos experimentar, ainda que de forma limitada, as delícias - e as inseguranças - da instabilidade e da precariedade da identidade.

Identidade precária ou a invisibilidade de Zucco. E como Fernanda afirma mais adiante, também do autor que amava a errância e ridicularizava a ideia de se ter raízes.

Zucco é um itinerante, em fuga, em viagem. Da mesma forma que o ator é este "viajante". O ator oferece sua bagagem para vestir qualquer personagem. O provisório e o transitório no ofício do ator 
- (BROOK, Peter. O teatro e seu espaço. Petrópolis: Vozes, 1970.) de teatro referem-se ao seu corpo instrumento, o lugar de muitas identidades, quase todas transitórias. E à ação no tempo presente, e, portanto provisória, qualidade fundamental do teatro.

Peter Brook, encenador fundamental do século XX, trabalha com a noção de precariedade no que diz respeito à ideia de construção. Refere-se ao senso comum em teatro relacionado à construção do personagem. Para ele, o personagem não pode ser erguido passo a passo como uma parede. Ao contrário, o personagem deve nascer e não ser construído, já que o papel construído é sempre o mesmo e a cada noite se desgasta. É este ator talhado para viver Zucco, que renasce a cada cena, ou estação como nos apresenta Fernanda.

Adiante, a autora enfatiza a relação de Koltès com os clássicos. Em especial Dostoiewski e Shakespeare. No caso de Shakespeare, na abertura de Roberto Zucco já nos deparamos com os dois guardas conversando e logo associamos com Hamlet, de Shakespeare. Se lá há um espectro do rei e se discute sua aparição, aqui temos Zucco se equilibrando pelo telhado, ele também de certa forma um espectro uma vez que os guardas não o veem. Em vários momentos do trabalho, Fernanda nos aponta referências a Shakespeare. Se fizermos uma leitura com este único objetivo encontraremos inúmeras possibilidades. É como se Koltès necessitasse antes apropriar-se dos clássicos reinventando-os, para então ousar sua própria escritura.

Um aspecto interessante marcado por Fernanda é a relação do dramaturgo com a iluminação. Suas construções revelam indicaçôes precisas sobre a luz da cena. Percebe-se em Zucco, um jogo interessante entre luz e sombra, entre claro e escuro. Determinadas situações necessitam de uma luz singular para que aconteçam. E assim evidencia-se um olhar debruçado sobre as palavras, mas que jamais perde de vista a cena.

Há um intenso estudo das passagens de cena em termos de sua localização e do momento em que ocorrem. É um minucioso exercício de observação e reflexão, como se a autora tentasse compreender os motivos do autor para sua determinação. Como por exemplo:

A cozinha da casa da garota e a delegacia, que deveriam ser lugares tranquilos e seguros, não o são. Por sua vez, o Petit Chicago deveria ser uma zona de risco, por onde circularia a escória da sociedade. Pelo contrário, a realidade se mostra outra: o bairro é calmo e suas dependências acolhem aqueles que ali chegam em busca de consolo ou abrigo. (p. 51) 
Quando reconhece no espaço um determinante da ação e mesmo das relaçôes entre as personagens, ela está reconhecendo no texto aquilo que é caro ao teatro e devolvendo a ele uma análise que o amplia.

É um tipo de informação que em termos da literatura revela intenções, propõe hipóteses e faz articulações entre as características dos personagens e sua ação no espaço. Em termos de teatro, traça um mapa do andamento da ação fazendo-nos compreender que estamos diante de uma composição singular, de uma dramaturgia que fragmenta e quer desenhar o mundo contemporâneo através da sua estrutura.

Assim, Fernanda nos mostra um dramaturgo que, além de escrever com maestria sobre a alma de seu tempo, explora a capacidade do teatro de ir a muitos lugares em pouco tempo, de cambiar espaços sem sair do espaço do palco, sem compromisso com o realismo, como no caso do cinema que exige locações.

Em Personagens, vemos esmiuçados o caráter e a imagem dos personagens, agrupando-os, incluindo, separando, fazendo novos conjuntos. Mais uma vez podemos imaginar como este material reagiria nas mãos dos artistas do palco. Pois, assim como Koltès, Fernanda é do teatro. E é seu olhar cênico que guia a trajetória da dissertação. Como está dito no texto do trabalho: "Somente no palco Koltès pôde criar os universos que desejava propor, desenhando o real sem confundir-se com ele, pois o teatro não passa de convenção." (p. 90)

Fernanda nos demonstra em vários momentos que, para Koltès, a ação está em lugar da motivação dos personagens. Eles agem. E falam. Personagens que se constroem na fala, na linguagem. Não se trata apenas de construir um texto vocalizado organicamente, mas em criar condiçôes em que a fala signifique mesmo a existência do personagem. Como Fernando Pessoa, que diz, "desde que vivo, narro-me”.

Brecht, apresenta seus personagens na medida em que agem em relação aos outros:

A aprendizagem de cada ator deve-se processar em conjunto com a dos outros atores, e, da mesma forma, a estruturação de cada personagem tem de ser conjugada com a das restantes. É que a unidade social mínima não é o homem, e sim dois homens. Também na vida real nos formamos uns aos outros.
* (PESSOA, Fernando. Livro do Desassossego. São Paulo, 1999: 501)

* (BRECHT, Bertolt. Estudos sobre teatro. Rio de Janeiro: Nova Fronteira, 1978: 123) 
* (LAROSSA, Jorge. La experiência de la lectura. Estúdios sobre literatura e formación. Barcelona: Laertes, 1996.)
Koltès, segundo Fernanda, também afirma através de seus personagens que eles estão no centro do confronto de forças e choques entre eles, ou seja, que eles se constituem na relação com o outro.

Ainda que o trabalho não siga até a encenação, nos são apresentados vários aspectos que denunciam a profunda teatralidade na obra de Koltès, como a presença do coro, recriado, ou as estaçôes como no teatro medieval.

A seguir, a autora elege autores contemporâneos e os apresenta ao seu leitor para comentar, concordar ou contrapor traços do trabalho de Koltès já delineados por ela. São vozes reconhecidas e respeitáveis que, ao seu lado, nos deixam mais fascinados pela figura singular do autor e a dimensão de sua obra. Ainda aqui, a forma com que a Dissertação está construída auxilia sobremaneira o caminho que vamos trilhando na descoberta de Bernard-Marie Koltès, Roberto Zucco e a nós próprios nesse emaranhado que nos é designado como mundo em que habitamos.

Salienta-se ainda o anexo, em que se desenha um panorama histórico do teatro francês do final do século XIX até o Nouveau Théâtre. Uma excelente contribuição incluída no trabalho de maneira a compreender a inserção da obra de Koltès no contexto da criação artística.

Jorge Larrosa* discute as questões e relações entre leitura e formação. Diz o autor que pensar a leitura como formação implica perceber não apenas o que o leitor sabe, mas aquilo que ele é, sua subjetividade. A leitura como algo que nos forma e transforma, que nos põe em questão, como algo que nos constitui. Ao mesmo tempo, ver a formação como leitura implica pensá-la como uma relação de sentido, como se tudo o que nos acontece pudesse ser considerado um texto, algo que põe em alerta nosso sentido de escuta. Ou seja, não importa somente o texto, mas a relação com o texto.

Ao estudar com tamanha profundidade o texto de Roberto Zucco, Fernanda nos oferece a possibilidade de, como ela mesma diz, reter um processo de criação no teatro. Se o espetáculo não permanece para além da memória de quem o viu, o texto literário fica, ainda e sempre, exposto a quem o quiser ler ou traduzir para o espaço da cena. 